\title{
Fatty acid composition of the longissimus dorsi muscle in crossbred steers fed different sources of fatty acids
}

\author{
Gabriela Aferri ${ }^{1}$, Paulo Roberto Leme ${ }^{2}$, Angélica Simone Cravo Pereira ${ }^{3}$, Saulo da Luz e \\ Silva $^{2}$, Soraia Marques Putrino ${ }^{2}$, José Esler de Freitas Júnior ${ }^{4}$, Francisco Palma Rennó ${ }^{3}$
}

\footnotetext{
1 Pólo Centro-Oeste, Agência Paulista de Tecnologia dos Agronegócios, SP, Brasil.

2 Faculdade de Zootecnia e Engenharia de Alimentos, Universidade de São Paulo, Pirassununga, SP, Brasil.

${ }^{3}$ Departamento de Nutrição e Produção Animal, Faculdade de Medicina Veterinária e Zootecnia, Universidade de São Paulo, Pirassununga, SP, Brasil.

${ }^{4}$ Curso de Pós-Doutorado Departamento de Nutrição e Produção Animal, Faculdade de Medicina Veterinária e Zootecnia, Universidade de
} São Paulo, Pirassununga,SP, Brasil.

\begin{abstract}
The objective of this study was to evaluate the fatty acid composition of the longissimus dorsi muscle in carcasses of $3 / 4$ Bos taurus taurus $1 / 4$ Bos taurus indicus steers fed different sources of fatty acids. Thirty-six steers aged 14 months, with a mean live weight of $320 \mathrm{~kg}$, were fed the following diets for 96 days: 1) control diet, containing no supplemental fat source; 2) CaSFA, diet containing $50 \mathrm{~g}$ calcium salts of fatty acids per $\mathrm{kg}$ total dry matter; 3) CS diet, containing $210 \mathrm{~g}$ cottonseed per $\mathrm{kg}$ total dry matter. The fatty acid composition of the longissimus dorsi muscle was determined by gas chromatography. No difference in slaughter weight, carcass weight, backfat thickness, or longissimus dorsi muscle area was observed between animals receiving the diets CaSFA and CS. Animals consuming the two fat-supplemented diets presented higher concentrations of oleic (C18:1), palmitic (C16:0) and stearic (C18:0) acids, corresponding to an average $80.76 \%$ of total fatty acids, and higher concentrations of vaccenic acid $(\mathrm{C} 18: 1 \mathrm{t} 11)$ in the muscle when compared with the control group. Supplementation of the diet of feedlot crossbred steers with CaSFA or cottonseed did not promote significant alterations in the lipid composition of the longissimus dorsi muscle.
\end{abstract}

Key Words: calcium salts, cottonseed, fat

\section{Introduction}

Beef is the most palatable and noble meat in all countries of the world, irrespective of individual socioeconomic condition (Prado, 2000). The biological characteristics of muscles, intramuscular fat and adipose tissue of the carcass are responsible for the dietary and organoleptic qualities of meat (Geay et al., 2001). The fatty acid composition of lipids present in meat is an important chemical and nutritional characteristic for human health, since it determines the function of fatty acids in the organism, and the presence of unsaturated fatty acids is desirable (French et al., 2000).

Fat supplementation of the ruminant diet may alter the fatty acid composition of meat. This change can be attributed to alterations in the process of ruminal biohydrogenation, which depends on the type and quantity of the fat source used. Biohydrogenation modifies the fatty acid profile of dietary lipids that will be available for intestinal absorption and is therefore one of the determining factors of the fatty acid composition of body fat in ruminants (Palmquist, 1996). Calcium salts of long-chain fatty acids (CaSFA) have been used as an additional energy source in diets for ruminants
(Jenkins \& Palmquist, 1984). The effects of CaSFA on performance and carcass traits have been studied in cattle, but no gain in production indices has been observed (Bartle et al., 1994; Ngidi et al., 1990; Hightshoe et al., 1991). In this respect, studies have investigated the effects of CaSFA supplementation of beef cattle diets on meat traits, especially the fatty acid composition (Partida et al., 2007; Silva et al., 2009). According to Coppock \& Wilks (1991), supplemental fats derived from oleaginous seeds enable the slow release of the oily fraction through the day due to regurgitation and remastication of the seeds. One type of oleaginous seeds commonly used in beef cattle diets in Brazil to reduce feeding costs is cottonseed. This seed has yielded results similar to those of other feeds in feedlot- or pasture-finished Nellore (Prado et al., 1995) and crossbred cattle (Moletta, 1992). However, Huerta-Leidenz et al. (1991) reported unfavorable results with the use of cottonseed in Hereford-Angus crossbreds.

Therefore, the objective of the present study was to determine the fatty acid composition of the longissimus dorsi muscle in steers supplemented with different sources of fatty acids. 


\section{Material and Methods}

The experiment was conducted at the facilities of the Coordinating Body of Pirassununga Campus, Universidade de São Paulo. Thirty-six $3 / 4$ Bos taurus taurus $\times$ $1 / 4$ Bos taurus indicus steers with a mean initial age of 14 months and live weight of $320 \mathrm{~kg}$ were kept in a feedlot. Steers were randomly divided into three groups of 12 animals each. The duration of the experimental period was 96 days, including 28 days of adaptation and 68 days in the feedlot (Aferri, et al., 2005).

The animals were kept in 18 partially covered pens equipped with a trough and automatic drinking bowl and received one of the following three diets (Table 1) formulated according to the CNCPS (2005): 1) control diet containing no supplemental fat; 2) diet containing $50 \mathrm{~g}$ calcium salts of long-chain fatty acids per kg total dry matter (CaSFA diet); 3 ) diet containing $210 \mathrm{~g}$ cottonseed per kg total dry matter (CS diet). Sugar cane was used as roughage throughout the experimental period.

Table 1 - Ingredients and chemical composition of the experimental diets

\begin{tabular}{|c|c|c|c|}
\hline \multirow[t]{2}{*}{ Ingredient ( $\mathrm{g} / \mathrm{kg}$ dry matter) } & \multicolumn{3}{|c|}{ Experimental diet } \\
\hline & Control & CS & CaSFA \\
\hline Sugar cane & 190.0 & 190.0 & 190.0 \\
\hline Soybean meal & 125.0 & 90.0 & 140.0 \\
\hline Corn & 293.6 & 211.8 & 265.4 \\
\hline Citrus pulp & 371.9 & 268.2 & 336.1 \\
\hline Calcium salts of fatty acids & - & - & 50.0 \\
\hline Cottonseed & - & 210.0 & - \\
\hline Urea & 9.5 & 5.0 & 8.5 \\
\hline Limestone & - & 15.0 & - \\
\hline Mineral $^{1}$ & 10.0 & 10.0 & 10.0 \\
\hline Rumensin & 0.2 & 0.2 & 0.2 \\
\hline \multicolumn{4}{|l|}{ Nutrients } \\
\hline DM & 784.6 & 794.8 & 792.1 \\
\hline $\mathrm{EE}$ & 25.1 & 67.9 & 69.7 \\
\hline MM & 53.7 & 54.0 & 63.4 \\
\hline $\mathrm{CP}$ & 144.0 & 142.2 & 144.4 \\
\hline RDP & 98.9 & 95.2 & 99.9 \\
\hline $\mathrm{TDN}^{2}$ & 819.8 & 778.9 & 771.1 \\
\hline \multicolumn{4}{|l|}{$\mathrm{g} / 100 \mathrm{~g}$ fatty acids } \\
\hline C14:0 & 0.064 & 0.214 & 0.138 \\
\hline C16:0 & 5.417 & 9.218 & 7.435 \\
\hline C18:0 & 1.347 & 1.559 & 1.503 \\
\hline $\mathrm{C} 18: 1$ cis & 5.516 & 7.568 & 7.481 \\
\hline C18:2 & 18.641 & 24.611 & 18.622 \\
\hline C18:3 & 2.575 & 1.878 & 2.676 \\
\hline Other & 0.388 & 0.279 & 0.415 \\
\hline Total fatty acids & 33.947 & 45.327 & 38.271 \\
\hline
\end{tabular}

CS - cottonseed; CaSFA - calcium salts of fatty acids (LAC $100^{\circledR}$ ).

${ }^{1}$ Composition per kg product: $\mathrm{Mg}-10 \mathrm{~g}$; S - $9 \mathrm{~g}$; Zn - 23,750 mg; Cu - 5,625 mg; Mn - 18,125 mg; Fe - 5,000 mg; Co - 125 mg; I - 312 mg; Se - 144 mg; F (maximum) $900 \mathrm{mg}$.

${ }^{2}$ Estimated by the formula of Weiss et al. (1992).
The animals were stunned with a pneumatic gun and slaughtered according to guidelines for the humane slaughter of cattle. The animals were bled through the jugular vein and carotid artery and the carcasses were individually identified. After cooling for $24 \mathrm{~h}$ at $2{ }^{\circ} \mathrm{C}$, the carcasses were cut between the 12th and 13th ribs for the evaluation of backfat thickness (in $\mathrm{mm}$ ) with a digital caliper. The longissimus dorsi muscle area (LMA) was measured using a grid $\left(\mathrm{cm}^{2}\right)$. A sample of the longissimus dorsi muscle was collected, vacuum stored, and frozen at $18^{\circ} \mathrm{C}$ for subsequent analysis.

For the determination of fatty acid composition, fat was extracted from the muscle according to the method of Hara \& Radin (1978). Five grams of the longissimus dorsi muscle (without subcutaneous fat) was mixed with $28 \mathrm{~mL}$ hexane/propanol $(3: 2, \mathrm{v} / \mathrm{v})$, homogenized for $1 \mathrm{~min}$, and vacuum-filtered. Next, a sodium sulfate solution $(67 \mathrm{mg} / \mathrm{mL})$ was added to obtain more than $50 \%$ of the filtered volume and the mixture was vortexed for $30 \mathrm{~s}$. The supernatant was transferred to tubes containing $2 \mathrm{~g}$ sodium sulfate and insufflated with nitrogen for $30 \mathrm{~s}$. The lipids were transferred to $10 \mathrm{~mL}$ tubes and the samples were stored at $-20{ }^{\circ} \mathrm{C}$ until methylation.

The extracted lipids were hydrolyzed and methylated as described by Christie (1983). About $40 \mathrm{mg}$ of lipids were transferred to tubes containing $2 \mathrm{~mL}$ hexane, $40 \mu \mathrm{L}$ methyl acetate were added, and the mixture was vortexed. Next, $40 \mu \mathrm{L}$ of the methylation solution $(1.75 \mathrm{~mL}$ methanol/ $0.4 \mathrm{~mL}$ sodium methoxide) was added. The mixture was agitated for $2 \mathrm{~min}$ and $60 \mu \mathrm{L}$ solution ( $1 \mathrm{~g}$ oxalic acid $/ 30 \mathrm{~mL}$ dietil eter), were shaken during $30 \mathrm{~s}$. About $200 \mathrm{mg}$ calcium chloride were added and the mixture was left to sit for $1 \mathrm{~h}$. The sample was centrifuged at $3200 \mathrm{rpm}$, calcium chloride was added, and the mixture was agitated for $5 \mathrm{~min}$ at $5{ }^{\circ} \mathrm{C}$. The supernatant was then pipetted and stored for subsequent analysis.

The methylated fatty acids were separated on a gas chromatograph (Thermo Finnigan, Thermo Electron Corp., MA, USA) equipped with a flame ionization detector and fused silica capillary column (Supelco SP-2560, Supelco, Inc., PA, USA $)(100 \mathrm{~m}, 0.25 \mathrm{~mm}$, and $0.2 \mu \mathrm{m})$. The temperature of the column was programmed to start at $70^{\circ} \mathrm{C}$ for $4 \mathrm{~min}$ and was increased to $170^{\circ} \mathrm{C}\left(13^{\circ} \mathrm{C} / \mathrm{min}\right)$ and $250^{\circ} \mathrm{C}\left(35^{\circ} \mathrm{C} / \mathrm{min}\right)$ for $5 \mathrm{~min}$. The flow rate was $1.2 \mathrm{~mL} / \mathrm{min}$ for the carrier gas (He). For the make-up gas, flow rates of 45 and $40 \mathrm{~mL} / \mathrm{min}$ were used for $\mathrm{N}_{2}$ and hydrogen, respectively. The injected sample volume was $1 \mu \mathrm{L}$. The temperatures of the injector and detector were 250 and $300{ }^{\circ} \mathrm{C}$, respectively. The fatty acids were identified by comparison of the retention time of the peaks with fatty acid standards (CRM-164, Commission 
of the European Communities, Community Bureau of Reference, Brussels, Belgium) and the results were expressed as percentage of the total fatty acids identified.

The results were analyzed by variance analysis using the PROC MIXED procedure of software SAS (Statistical Analysis System, version 9.1). The Tukey test was used for comparison of treatment means, adopting a significance level of 0.05

\section{Results and Discussion}

No significant difference $(\mathrm{P}>0.05)$ in slaughter weight, carcass weight, backfat thickness, or LMA was observed between animals receiving the CaSFA and CS diets (Table 2). Fat accumulation in feedlot cattle, which may influence carcass yield and consequently LMA, is normally associated with energy supplementation of the diet. However, the diets of the present study were formulated to meet the requirements of finishing cattle. Thus, the ether extract and total digestible nutrient content of the two diets was similar.

Paulino et al. (2002) also found no difference in hot carcass weight between feedlot cattle receiving soybean and cottonseed. Similarly, Ngidi et al. (1990) and Zinn et al. (2000) observed no difference in carcass fat thickness or LMA between steers fed CaSFA. On the other hand, HuertaLeidenz et al. (1991), evaluating the addition of $15 \%$ and $30 \%$ whole cottonseed to the cattle diet, observed a reduction in carcass weight and LMA. However, the authors found no differences in subcutaneous fat thickness of the longissimus dorsi muscle.

Higher concentrations of oleic (C18:1), palmitic (C16) and stearic (C18:0) acids were detected in the longissimus dorsi muscle samples of animals receiving the CaSFA and CS diets, corresponding to an average of $80.76 \%$ of total fatty acids (Table 3 ). The proportion of saturated fatty acids in beef is in fact lower than that of total polyunsaturated fatty acids and consists mainly of palmitic (C16:0) and stearic (C18:0) acids. The latter accounts for about $40 \%$ of saturated fat and does not increase the plasma cholesterol levels. Similar fatty acid concentrations have been reported by Scollan et al. (2001), who evaluated different sources of polyunsaturated fatty acids in steers. In that study, oleic, palmitic and stearic acids corresponded to $81.80 \%$ of total fatty acids in the control diet. Cifuni et al. (2004) investigated the fatty acid profile of young feedlot bulls and found that oleic and stearic acids accounted for more than $50 \%$ of the total fatty acids.

According to Duckett et al. (2002), intramuscular fat consists of a variety of fatty acids. However, oleic, palmitic, stearic, linoleic, palmitoleic and myristic acids represent more than $92 \%$ of all fatty acids. In addition, ruminant fat is the only one that contains fatty acids derived from the ruminal biohydrogenation of dietary lipids.

Saturated fatty acids are important for human health, since they are classified as hypercholesterolemic. In the present study, the different sources of dietary lipids did not alter $(\mathrm{P}>0.05)$ the proportion of caproic $(\mathrm{C} 6: 0)$, capric $(\mathrm{C} 10: 0)$, lauric (C12:0), myristic (C14:0), pentadecanoic (C15:0), or stearic (C18:0) acids. In contrast, Preston et al. (1998) observed an increase of stearic acid (C18:0) concentration in subcutaneous fat when cattle were fed a diet containing cottonseed. On the other hand, the concentration of margaric acid (C17:0) was lower in animals fed the CS diet. Andrae et al. (2001) showed that feeding steers high-oil corn increased the margaric acid content in the longissimus muscle. Ito et al. (2005) observed higher concentrations of margaric acid in the longissimus dorsi muscle of cattle receiving diets containing ground corn when compared with animals fed diets that contained soybean oil and flaxseed.

Intramuscular fat consists of approximately 20 fatty acids, with six of these fatty acids (oleic, palmitic, stearic, linoleic, palmitoleic, and myristic acid) accounting for $92 \%$ of all fatty acids. Odd-chain fatty acids such as pentadecylic acid (C15:0) and margaric acid (C17:0) are also found in intramuscular fat. These fatty acids are synthesized from propionate and valerate by bacteria present in microbial lipids (Mansbridge \& Blake, 1997). In the present study, no difference in the content of palmitic acid (C16:0), an important fatty acid found in large amounts in meat, was observed between animals receiving the fat-supplemented diets and

Table 2 - Slaughter weight, carcass weight, backfat thickness and longissimus muscle area of animals receiving the different diets during the experimental period

\begin{tabular}{|c|c|c|c|c|c|}
\hline \multirow[t]{2}{*}{ Trait } & \multicolumn{3}{|c|}{ Experimental diet } & \multirow[t]{2}{*}{$\mathrm{P}$ value } & \multirow[t]{2}{*}{$\mathrm{CV}(\%)$} \\
\hline & Control & CS & CaSFA & & \\
\hline Slaughter weight $(\mathrm{kg})$ & 444.0 & 428.0 & 430.0 & 0.543 & 8.7 \\
\hline Carcass weight (kg) & 250.0 & 242.0 & 244.0 & 0.711 & 9.2 \\
\hline $\mathrm{BF}(\mathrm{mm})$ & 5.5 & 5.3 & 5.3 & 0.973 & 34.5 \\
\hline LMA $\left(\mathrm{cm}^{2}\right)$ & 66.9 & 66.9 & 71.5 & 0.344 & 12.8 \\
\hline
\end{tabular}

CS - cottonseed; CaSFA - calcium salts of fatty acids $\left(\right.$ LAC $\left.100^{\circledR}\right)$; BF - backfat thickness; LMA - longissimus dorsi muscle area; CV - coefficient of variation. 
the control diet $(\mathrm{P}>0.05)$. However, the concentration of this fatty acid was lower in animals fed the CaSFA diet compared with those receiving the $\mathrm{CS} \operatorname{diet}(\mathrm{P}<0.05)$. Palmitic acid (16:0) is a saturated and highly digestible fatty acid found in different feedstuffs. According to Weiss (2004), this fatty acid is present in diets containing CaSFA. Silva et al. (2009) observed no differences in the C16:0 concentration between Nellore steers fed diets with and without CaSFA. Huerta-Leidenz et al. (1991) found no difference in the C16:0 concentration of subcutaneous adipose tissue samples between steers fed whole cottonseed and control animals, and the levels were similar to those seen in the present study. The concentrations of myristoleic (C14:1 c9), palmitoleic (C16:1 c9), oleic (C18:1 c9), asclepic (C18:1 c11), monounsaturated fatty acids and $\mathrm{c} 12$ and $\mathrm{t} 16$ octadecenoic acid (C18:1) were unchanged in animals receiving the diets. Higher muscle concentrations of $\mathrm{C} 17: 0$ and C17:1 were observed in animals receiving the control diet compared with those fed the CS and CaSFA diets. This result differs from the findings reported by Silva et al. (2009), who observed a reduction of the $\mathrm{C} 17: 1$ concentration in animals receiving CaSFA compared with the control diet $(\mathrm{P}<0.05)$. One explanation for these divergent results may be differences in the composition of the diets offered to the animals. The CaSFA diet promoted higher muscle concentrations of vaccenic acid (C18:1 t11) compared with the control diet $(\mathrm{P}<0.05)$. However, no difference in the concentration of this fatty acid was observed between animals receiving the $\mathrm{CS}$ and CaSFA diets $(\mathrm{P}>0.05)$. These higher concentrations of vaccenic acid might be attributed to the higher intensity of ruminal biohydrogenation as a result of increased fat intake. However, the optimal concentrations of conjugated linoleic acids (CLA) that promote beneficial effects on human health are still unknown (Nelson et al., 2008).

Trans-vaccenic acid is the major trans-isomer (18:1) in meat and the precursor of CLA in animal and human tissues. this fatty acid exerts neutral to beneficial effects (Scollan et al., 2006). Although some studies suggest that feeding animals CLA-rich oils alters the concentration of this fatty acid, no increase was observed in the present study in animals receiving the fat-supplemented diets. With respect to polyunsaturated fatty acids, no differences in the proportion of linoleic acid (C18:2 c9c12), and t10c12-, t9t11and c9t11-CLA-octadecadienoic octadecadienoic acid (C18:2) were observed between animals fed the supplemented and control diets. However, the concentration of octadecadienoic acid (C18:2 $\mathrm{t} 11 \mathrm{c} 15)$ was higher in animals fed the CaSFA diet compared with the other groups $(\mathrm{P}<0.05)$.
Therefore, although increasing the amount of CLA precursors in the rumen, the addition of cottonseed and CaSFA is still insufficient to alter CLA concentrations in meat. Further studies are needed to clarify this aspect. Beaulieu et al. (2002) also found no differences in the CLA concentration in meat of heifers supplemented with soybean oil. Similarly, Hristov et al. (2005) observed no difference in CLA content between steers fed linoleic acid- or oleic acidrich diets. According to Regitano (2005), these fatty acids correspond to $74 \%$ of all fatty acids in cottonseed. The present study showed a significant difference in the linolenic acid ( $\mathrm{C} 18: 3)$ content $(\mathrm{P}=0.010)$, with the observation of lower levels in longissimus dorsi muscle samples of animals receiving the $\mathrm{CS}$ diet, which is poor in linolenic acid, when compared with the other groups

No significant difference $(\mathrm{P}>0.05)$ in total fatty acids [saturated (SFA), monounsaturated (MUFA) and polyunsaturated fatty acids (PUFA)] was observed between animals receiving the different diets (Table 3 ). Abrahão et al. (2008) found no difference in the percentage of SFA (46\%), MUFA (45\%) and PUFA ( $8 \%$ ) between crossbred animals of different genetic groups. However, the levels were different from those seen in the present study. Partida et al. (2007) also demonstrated that supplementation of young bulls with CaSFA did not influence the proportion of SFA in meat, except for C16:0 and C18:0 acids. In contrast, Scollan et al. (2003) observed a decrease and increase in the proportion of $\mathrm{C} 16: 0$ and $\mathrm{C} 18: 0$ acids, respectively, in steers receiving CaSFA.

No difference in the MUFA $(\mathrm{P}=0.99)$ or PUFA $(\mathrm{P}=0.12)$ content was observed between animals receiving the different experimental diets. On the other hand, Felton \& Kerley (2004) showed that the administration of soybean rich in oil increased the proportion of PUFA and reduced that of MUFA in muscle samples of steers. In the present study, the diet containing cottonseed-based concentrate did not increase the PUFA content, which is an unexpected finding, since linoleic acid accounts for more than half of the fatty acids of cottonseed oil. In general, animals with lower intramuscular fat deposition rates present a more polyunsaturated profile, since intramuscular fat consists of SFA and MUFA, whereas PUFA are almost exclusively found in phospholipids of the muscle cell membrane (Duckett et al., 1993).

Animals receiving the CaSFA diet presented more desirable MUFA/SFA and PUFA/SFA ratios. However, the MUFA/SFA ratio was lower in animals fed the control diet and the PUFA/SFA ratio was lower in animals receiving the CS diet. This finding might be attributed to the higher 
Table 3 - Mean fatty acid composition of lipids in the longissimus dorsi muscle of steers fed different sources of fatty acids

\begin{tabular}{|c|c|c|c|c|c|}
\hline \multirow[t]{2}{*}{ Fatty acid $(\mathrm{g} / 100 \mathrm{~g}$ total fatty acids) } & \multicolumn{3}{|c|}{ Experimental diet } & \multirow[t]{2}{*}{$P$ value } & \multirow[t]{2}{*}{$\mathrm{CV}(\%)$} \\
\hline & Control & $\mathrm{CS}$ & CaSFA & & \\
\hline C6:0 & 0.047 & 0.067 & 0.094 & 0.219 & 57.71 \\
\hline $\mathrm{C} 12: 0$ & 0.052 & 0.022 & 0.052 & 0.341 & - \\
\hline $\mathrm{C} 14: 0$ & 3.701 & 3.501 & 3.498 & 0.767 & 16.77 \\
\hline C14:1 c9 & 0.691 & 0.567 & 0.464 & 0.153 & 29.70 \\
\hline Anteiso-C15:0 & 0.108 & 0.085 & 0.127 & 0.148 & 30.42 \\
\hline C16:0 & $29.196 \mathrm{ab}$ & $30.129 \mathrm{a}$ & $28.224 b$ & 0.046 & 3.64 \\
\hline Iso-C $16: 0$ & 0.078 & 0.065 & 0.082 & 0.456 & 30.99 \\
\hline C16:1 c-9 & 3.288 & 3.339 & 2.945 & 0.445 & 16.63 \\
\hline $\mathrm{C} 17: 0$ & $1.016 \mathrm{a}$ & $0.759 \mathrm{~b}$ & $0.996 a$ & 0.005 & 13.33 \\
\hline Iso-C $17: 0$ & 0.190 & 0.166 & 0.207 & 0.589 & 33.21 \\
\hline C18:1 c-12 & 0.434 & 0.511 & 0.536 & 0.554 & 12.45 \\
\hline C18:1 t-11 vaccenic acid & $2.644 b$ & $3.077 \mathrm{a}$ & $5.849 \mathrm{ab}$ & 0.005 & 30.43 \\
\hline $\mathrm{C} 18: 1 \mathrm{t}-16$ & 0.336 & 0.254 & 0.261 & 0.502 & 45.68 \\
\hline C18:2 c-9,c-12 & 2.691 & 2.166 & 2.618 & 0.118 & - \\
\hline C18:2 c-9,t-11 CLA & 0.363 & 0.440 & 0.292 & 0.074 & 19.88 \\
\hline C18:2 t-10,c-12 CLA & 0.028 & 0.016 & 0.061 & 0.432 & 17.62 \\
\hline $\mathrm{C} 18: 2 \mathrm{t}-11, \mathrm{c}-15$ & $0.009 \mathrm{~b}$ & $0.000 \mathrm{~b}$ & $0.072 \mathrm{a}$ & 0.005 & 24.41 \\
\hline C18:2 t-9,t-11 & 0.082 & 0.093 & 0.239 & 0.482 & - \\
\hline C18:3 c-9,c-12,c-15 & $0.298 \mathrm{a}$ & $0.207 \mathrm{~b}$ & $0.272 \mathrm{a}$ & 0.010 & - \\
\hline \multicolumn{6}{|l|}{ Total } \\
\hline $\mathrm{SFA}^{1}$ & 47.161 & 47.046 & 46.462 & 0.798 & 3.55 \\
\hline
\end{tabular}

CS - cottonseed; CaSFA - calcium salts of fatty acids (LAC $\left.100^{\circledR}\right)$; CV - coefficient of variation.

${ }^{1}$ Saturated fatty acids: sum of C6:0, C10:0, C12:0, C14:0, C15:0, iso-C15:0, anteiso-C15:0, C16:0, C17:0, iso-C17:0, and C18:0.

2 Monounsaturated fatty acids: sum of C14:1 c9, C16:1 c-9, C17:1, anteiso-C17:1, C18:1 c-9, C18:1 c-11, C18:1 c-12, C18:1 t-11, and C18:1 t-16.

${ }^{3}$ Polyunsaturated fatty acids: sum of C18:2 t-11,c-15, C18:2 c-9,c-12, C18:2 c-9,t-11, C18:2 c-9,t-11, C18:2 t-10,c-12, and C18:3 c-9,c-12,c-15.

${ }^{4} \mathrm{n}-3$ fatty acids: sum of C18:2 t-11, c-15 and C18:3 c-9,c-12,c-15.

5 n-6 fatty acids: sum of C18:1 c-12, C18:2 t-10, c-12, and C18:2 c-9,c-12.

concentration of $\mathrm{C} 18: 2 \mathrm{t} 11 \mathrm{c} 15$ fatty acid seen in animals fed CaSFA. Simopoulos et al. (1999) emphasized the importance of reducing $\omega-6$ PUFA and increasing $\omega-3$ PUFA in the human diet for adequate mental and cardiovascular health and function. Studying Nellore steers fed CaSFA, Silva et al. (2009) reported a PUFA/SFA ratio ranging from 0.06 to 0.07 , probably as a result of lower PUFA concentrations, with levels similar to those observed in the present study.

No difference in total $\omega 6$-fatty acids was observed between the diets analyzed $(\mathrm{P}>0.05)$. In contrast, $\omega 3$-fatty acid levels were higher in animals receiving the CaSFA diet $(\mathrm{P}<0.05)$. This is desired, since an increase of $\omega 3$-fatty acids may increase the perception of meat as a healthy food
(Laborde et al., 2001). The positive effects of $\omega 3$-fatty acids include antiatherogenic, antithrombotic and antiinflammatory properties (Givens et al., 2006). Scollan et al. (2006) suggested that increasing the nutritional value of meat can stimulate product differentiation, promoting better acceptance by the consumer.

Animals fed the CS diet presented a higher $\omega 6 / \omega 3$ ratio (12.8:1) than those receiving the CaSFA diet (9.4:1) (Table 3). The $\omega 6 / \omega 3$ ratios observed in the present study are higher than those reported by Partida et al. (2007) and French et al. (2000). The ideal ratio should be lower than 4 and not exceed 25. No increase in total $\omega$-6-fatty acids was observed in the present study. However, the higher $\omega$-3-fatty acid content improved the $\omega-6 / \omega-3$ ratio, 
particularly in animals fed the CaSFA diet. According to Cifuni et al. (2004), total fatty acid content and PUFA/SFA and $\omega-6 / \omega-3$ ratios are important indicators of the nutritional value of feedstuffs when healthier diets for humans are considered.

\section{Conclusions}

The addition of CaSFA and cottonseed to the diet of crossbred feedlot steers does not alter the lipid composition of the longissimus dorsi muscle. Thus, no conclusions can be drawn as for whether or not these supplemented diets improve the fatty acid profile of steer meat.

\section{References}

ABRAHÃO, J.J.S.; MARQUES, J.A.; MACEDo, L.M. et al. Composição química e perfil de ácidos graxos do músculo Longissimus de bovinos de diferentes grupos genéticos terminados em confinamento. Acta Scientiarum. Animal Science, v.30, p.443-449, 2008.

AFERRI, G.; LEME, P.R.; SILVA, S.L et al. Desempenho e características de carcaça de novilhos alimentados com dietas contendo diferentes fontes de lipídios. Revista Brasileira de Zootecnia, v.34, n.5, p.1651-1658, 2005.

ANDRAE, J.G.; DUCKETT, S.K.; HUNT, C.W. Effects of feeding high-oil corn to beef steers on carcass characteristics and meat quality. Journal of Animal Science, v.79, p.582-588, 2001.

BARTLE, S.J.; PRESTON, R.L.; MILLER, M.F. Dietary energy source and density: effects of roughage source roughage equivalent, tallow level, and steer type on feedlot performance and carcass characteristics. Journal of Animal Science, v.72, n. 8, p.1943-1953, 1994.

BEAULIEU, A.D.; DRACKLEY, J.K.; MERCHEN, N.R. et al. Concentrations of conjugated linoleic acid (cis-9, trans-11octadecadienoic acid) are not increased in tissue lipids of cattle fed a high-concentrate diet supplemented with soybean oil. Journal of Animal Science, v.80, p.847-861, 2002.

CIFUNI, G.F.; NAPOLITANO, F.; RIVIEZZI, A.M. et al. Fatty acid profile, cholesterol content and tenderness of meat from Podolian young bulls. Meat Science, v.67, p.289-297, 2004.

CHRISTIE, W.W. A simple procedure for rapid transmethylation of glycerolipids and cholesteryl esters. Journal of Lipid Research, v.23, p.1072-1075, 1983.

COPPOCK, C.E.; WILKS, D.L. Supplemental fat in high-energy rations for lactating cows: effect on intake, digestion, milk yield and composition. Journal of Animal Science, v.69, p.3826-3837, 1991.

DUCKETT, S.K.; ANDRAE, J.G.; OWENS, F.N. Effect of high-oil corn or added corn oil on ruminal biohydrogenation of fatty acids and conjugated linoleic acid formation in beef steers fed finishing diets. Journal of Animal Science, v.80, p.3353-3360, 2002.

DUCKETT, S.K.; WAGNER, D.G.; YATES, L.D. et al. Effects of time on feed on beef nutrient composition. Journal of Animal Science, v.71, p.2079-2088, 1993

FELTON, E.E.D.; KERLEY, M.S. Performance and carcass quality of steers fed different sources of dietary fat. Journal of Animal Science, v.82, p.1794-1805, 2004.

FRENCH, P.; STANTON, C.; LAWLESS, F. et al. Fatty acid composition, including conjugated linoleic acid, of intramuscular fat from steers offered grass, grass silage, or concentrate-based diets. Journal of Animal Science, v.78, p.2849-2855, 2000.
GEAY, Y.; BAUCHART, D.; HOCQUETTE, J. Effect of nutritional factors on biochemical, structural and metabolic characteristics of muscles in ruminants, consequences on dietetic value and sensorial qualities of meat. Reproduction Nutrition Development, v.41, p.1-26, 2001.

GIVENS, D.I.; KLIEM, K.E.; GIBBS, R.A. The role of meat as a source of $n_{-} 3$ polyunsaturated fatty acids in the human diet. Meat Science, v.74, p.209-218, 2006.

HARA, A.; RADIN, N.S. Lipid extraction of tissues of low-toxicity solvent. Analytical Biochemistry, v.90, p.420-426, 1978.

HIGHTSHOE, R.B.; COCHRAN, R.C.; CORAH, L.R. et al. Effects of calcium soaps of fatty acids on postpartum reproductive function in beef cows. Journal of Animal Science, v.69, p.4097-4103, 1991.

HRISTOV, A.N.; KENNINGTON, L.R.; MCGUIRE, M.A. et al. Effect of diets containing linoleic acid- or oleic acid-rich oils on ruminal fermentation and nutrient digestibility, and performance and fatty acid composition of adipose and muscle tissues of finishing cattle. Journal of Animal Science, v.83, p.312-1321, 2005.

HUERTA-LEIDENZ, N.O.; CROSS, H.R.; LUNT, D.K. Growth, carcass traits, and fatty acid profiles of adipose tissues from steers fed whole cottonseed. Journal of Animal Science, v.69, p.3665-3672, 1991.

ITO, R.H.; SOUZA, N.E.; PRADO, J.M. et al. Perfil de ácidos graxos do músculo "Longissimus dorsi" de bovinos mestiços inteiros terminados em confinamento alimentados com óleo de soja e semente de linhaça. In: REUNIÃO ANUAL DA SOCIEDADE BRASILEIRA DE ZOOTECNIA, 42., 2005, Goiânia. Anais... Goiânia: Sociedade Brasileira de Zootecnia, 2005. 5p. (CD-ROM).

JENKINS, T.C.; PALMQUIST, D.L. Effect of fatty acid or calcium soaps on rumen and total nutrient digestibility of dairy rations. Journal of Dairy Science, v.67, p.9721, 1984.

LABORDE, F.L.; MANDELL, I.B.; TOSH, J.J. et al. Breed effects on growth performance, carcass characteristics, fatty acid composition, and palatability attributes in finishing steers Journal of Animal Science, v.79, p.355-365, 2001.

MANSBRIDGE, R.J.; BLAKE, J.S. Nutritional factors affecting the fatty acid composition of bovine milk. British Journal of Nutrition, v.78, suppl.1, p.S37-S47, 1997.

MOLETTA, J.L.; RESTlE, J. Desempenho em confinamentos de novilhos de diferentes grupos genéticos. Ciência Rural, v.22, n.2, p.227-233, 1992.

NELSON, M.L.; BUSBOON, J.R.; ROSS, C.F. et al. Effects of supplemental fat on growth performance and quality of beef from steers fed corn finishing diets. Journal of Animal Science, v.86, p.936-948, 2008 .

NGIDI, M.E.; LOERCH, S.C.; FLUHARTY, F.L. et al. Effects os calcium soaps of long-chain fatty acids on feedlot performance, carcass characteristics and ruminal metabolism of steers. Journal of Animal Science, v.68, p.2555-2565, 1990.

PALMQUIST, D.L. Utilización de lípidos en dietas de rumiantes. In: CURSO DE SPECIALIZACIÓN, 12., 1996, Madrid. Proceedings... Madrid: FEDNA, 1996. Available at: $<$ www.etsia.upm.es/fedna/capitulos/96capituloIII.pdf.> Accessed on: June 20, 2005.

PARTIDA, J.A.; OLLETA, J.L.; SAÑUDO, C. et al. Fatty acid composition and sensory traits of beef fed palm oil supplements. Meat Science, v.76, p.444-454, 2007.

PRADO, I.N.; OLIVEIRA, P.S.; DAMASCENO, J.C. et al. Efeito da substituição do farelo de soja pelo farelo de canola sobre o consumo e digestibilidde aparente em novilhas. In: REUNIÃO ANUAL DA SOCIEDADE BRASILEIRA DE ZOOTECNIA, 32 ., 1995, Brasília. Anais... Brasília: SBZ, 1995. p.319-320.

PRADO, I.N. Comercialização e estratégias competitivas na cadeia de carnes no Brasil. Maringá: Eduem, 2000. 139p.

PRESTON, R.L.; BARTLE, S.J.; RULE, D.C. et al. Effect of whole cottonseeds in cattle finishing diets on growth, efficiency and 
body fat composition. Journal of Animal Science, v.2, p.505-506, 1998.

REGITANO D'ARCE, M.A.B. Grãos e óleos vegetais: matérias primas. Available at: <www.esalq.usp.br/departamentos/ln/pdf/ 2444materiasprimas.pdf $>$. Accessed on: June 20, 2005.

SCOLLAN, N.D.; CHOI, N.; KURT, E. et al. Manipulating the fatty acid composition of muscle and adipose tissue in beef cattle. British Journal of Nutrition, v.85, p.115-124, 2001.

SCOLLAN, N.D.; ENSER, M.; GULATI, S. et al. Effect of including a ruminally protected lipid supplement in the diet on the fatty acid composition of beef muscle in Charolais steers. British Journal of Nutrition, v.90, p.709-716, 2003.

SCOLlAN, N.D.; HOCQUETE, J.; NUERNBERG, K. et al. Innovations in beef production systems that enhance the nutritional and health value of beef lipids and their relationship with meat quality. Meat Science, v.74, p.17-33, 2006.
SILVA, S.L.; LEME, P.R.; PUTRINO, S.M. Fatty acid composition of intramuscular fat from Nellore steers fed dry or high moisture corn and calcium salts of fatty acids. Livestock Science, v.122, p.290-295, 2009.

SIMOPOULOS, A.P.; LEAF, A.; SALEM JUNIOR, N. Essentiality of and recommended dietary intakes for omega- 6 and omega- 3 fatty acids. Annals of Nutrition \& Metabolism, v.43, p.127-130, 1999.

ZINN, R.A.; GULATI S.K.; PLASCENCIA A. et al. Influence of ruminal biohydrogenation on the feeding value of fat in finishing diets for feedlot cattle. Journal Animal Science, v.78, p. $1738,2000$.

WEISS, W.P.; CONRAD, H.R.; PIERRE, N.R.ST. A theoreticalbased model for predicting total digestible nutrient values of forages and concentrates. Animal Feed Science and Technology, v.39, p. $95-110,1992$. 